\title{
Surface Area Effect of Zinc Oxide for Steam Reforming of Ethanol over Supported-Platinum Catalysts*
}

\author{
Josh Y. Z. Chiou, Wen-Yzu Wang, and Chen-Bin Wang ${ }^{\dagger}$ \\ Department of Chemical and Materials Engineering, Chung Cheng Institute of Technology, \\ National Defense University, Tahsi, Taoyuan 33509, Taiwan, ROC \\ Chuin-Tih Yeh \\ Department of Chemical Engineering and Materials Science, \\ Yuan Ze University Chungli, Taoyuan, 32003, Taiwan, ROC, and \\ Fuel Cell Center, Yuan Ze University, Chungli, Taoyuan, 32003, Taiwan, ROC \\ (Received 30 December 2011; Accepted 8 June 2012; Published 25 August 2012)
}

\begin{abstract}
The effect of surface area over the $\mathrm{ZnO}$-supported platinum catalysts on the catalytic performance of steam reforming of ethanol (SRE) has been studied. Various surface area of $\mathrm{ZnO}$ is prepared through two routes: reflux (assigned as ZnO-R), thermal decomposition under air (assigned as $\mathrm{ZnO}-\mathrm{A}$ ) and under $\mathrm{N}_{2}$ (assigned as $\mathrm{ZnO}-\mathrm{N}$ ). Also, the commercial $\mathrm{ZnO}$ (assigned as $\mathrm{ZnO}-\mathrm{C}$ ) is chosen as reference. Four Pt/ZnO catalysts (3 wt\% loading of $\mathrm{Pt}$ ) are prepared by incipient wetness impregnation (assigned as $\mathrm{Pt}-\mathrm{R}, \mathrm{Pt}-\mathrm{A}, \mathrm{Pt}-\mathrm{N}$ and $\mathrm{Pt}-\mathrm{C}$, respectively). The BET measurement shows that the $\mathrm{ZnO}-\mathrm{A}\left(89 \mathrm{~m}^{2} \cdot \mathrm{g}^{-1}\right)$ support possesses a higher surface area than the ZnO-R (1.3 $\left.\mathrm{m}^{2} \cdot \mathrm{g}^{-1}\right)$. The catalytic activity on the SRE reaction is evaluated in a fixed-bed reactor under $22,000 \mathrm{~h}^{-1} \mathrm{GHSV}$ and $\mathrm{H}_{2} \mathrm{O} / \mathrm{EtOH}$ molar ratio of 13 . The results show that total ethanol conversion is observed at $225^{\circ} \mathrm{C}$ and $400^{\circ} \mathrm{C}$ over the Pt-A and Pt-R catalysts, respectively. When the temperature exceeds $350^{\circ} \mathrm{C}$, acetaldehyde decomposition and acetaldehyde steam reforming are competitive on the platinum catalysts to promote $\mathrm{H}_{2}$ production. The small particle size catalyst of Pt-A favors the decomposition of acetaldehyde to produce $\mathrm{CH}_{4}$ and $\mathrm{CO}$, and the large particle size catalyst of Pt-R favors the steam reforming of acetaldehyde to produce $\mathrm{CH}_{4}$ and $\mathrm{CO}_{2}$.
\end{abstract}

[DOI: 10.1380/ejssnt.2012.431]

Keywords: Zinc oxide; Surface area; Steam reforming of ethanol; Platinum

\section{INTRODUCTION}

Hydrogen is considered a potential source of clean energy, mainly because of its use as fuel in fuel-cell systems. However, to date, the production of hydrogen is still based on the reforming of fossil-derived fuels [1-3]. Several biomass sources can be supplied to produce hydrogen by the steam reforming reaction. The steam reforming of ethanol (SRE) is an endothermic reaction which produces 6 mole $\mathrm{H}_{2}$ per mole of ethanol. However, other side reactions can also occur, such as dehydration, dehydrogenation, decomposition and condensation. These reactions result in undesirable products, such as ethylene, acetone, methane or $\mathrm{CO}$, which interfere with the process. A catalyst under certain reaction conditions favors a reaction or a group of reactions among the possible network of reactions described above.

Llorca et al. [4] were the first to show that pure $\mathrm{ZnO}$, among oxides such as alumina, magnesia, ceria and titania, was the most active, at temperatures as low as $400^{\circ} \mathrm{C}$, in producing hydrogen from bio-ethanol. Also, the addition of cobalt to $\mathrm{ZnO}$ further upgraded the activity of the SRE reaction at low temperatures $[5,6]$. $\mathrm{ZnO}$ and $\mathrm{ZnO}$-supported catalysts have performed well in SRE reactions, possibly because $\mathrm{ZnO}$ has both hydrogenation/dehydrogenation activities and basic properties. Yang et al. [7] reported that $\mathrm{ZnO}-, \mathrm{La}_{2} \mathrm{O}_{3^{-}}, \mathrm{MgO}-$ and $\mathrm{Al}_{2} \mathrm{O}_{3}$-supported nickel catalysts were highly active

* This paper was presented at the 6th International Symposium on Surface Science - Towards Nano, Bio and Green Innovation-, Tower Hall Funabori, Tokyo, Japan, December 11-15, 2011.

†Corresponding author: chenbinwang@gmail.com

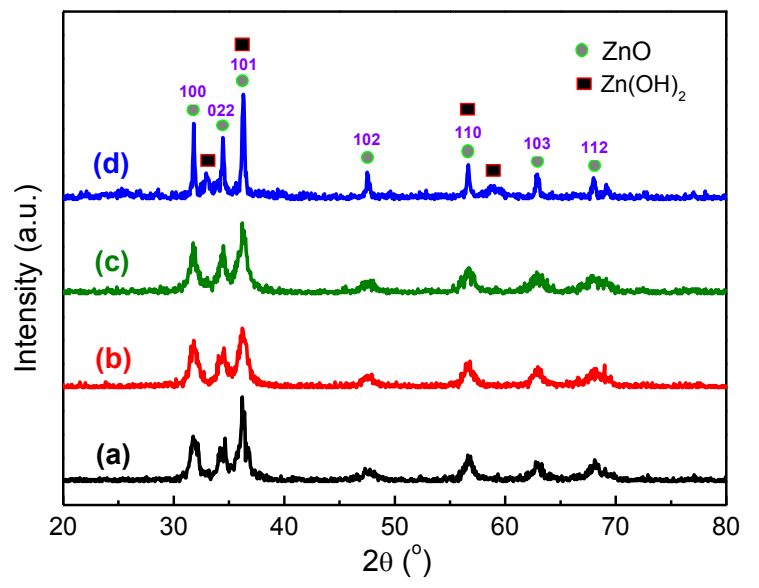

FIG. 1: XRD patterns of $\mathrm{ZnO}$ supports: (a) $\mathrm{ZnO}-\mathrm{C}$ (b) $\mathrm{ZnO}-\mathrm{A}$ (c) $\mathrm{ZnO}-\mathrm{N}$ (d) $\mathrm{ZnO}-\mathrm{R}$.

at temperatures from $330-650^{\circ} \mathrm{C}$, but that their product distributions strongly depended on the support material and the nickel loading. The effect of zinc oxide loading on the catalytic activity and product selectivity in the catalytic reforming of bio-ethanol has been reported for $\mathrm{ZnO}$-supported silica catalysts [8]. In addition, in order to understand the role of acetaldehyde on product distribution during the catalytic reforming of bio-ethanol, the steam reforming of acetaldehyde over $\mathrm{ZnO} / \mathrm{SiO}_{2}$ catalysts also has been studied. It is likely that a better dispersion of the catalysts would be beneficial for the catalytic activity $[9,10]$.

Reforming reactions over $\mathrm{ZnO}$-supported noble metalbased catalysts, such as $\mathrm{Co}, \mathrm{Cu}$ and $\mathrm{Ni}$, have shown 
a high efficiency in the production of hydrogen $[7,10$ 13]. Moreover, the morphology effect of $\mathrm{ZnO}$-supported catalysts [14], doping extra metal in the catalytic system $[15,16]$ and using a new type of multi-layered reformer [17] to modify the $\mathrm{Co} / \mathrm{ZnO}$ catalytic system and promote the catalytic performance were reported on recently. In the literature there have been some reports that Pt-based catalysts on different supports, including $\mathrm{CeO}_{2}$, $\mathrm{ZrO}_{2}, \mathrm{CeZrO}_{2}$ and $\mathrm{Al}_{2} \mathrm{O}_{3}$ [18-23], exhibited good activity for hydrogen production. Recently, we investigated how $\mathrm{ZrO}_{2}, \mathrm{Al}_{2} \mathrm{O}_{3}$ and $\mathrm{ZnO}$-supported $\mathrm{Pt}$ catalysts promoted the reforming of ethanol, where the loading of $\mathrm{Pt}$ and support effects were studied [24-26]. In this work, four kinds of zinc oxide with different surface area were prepared and chose as the supports in designing the $\mathrm{ZnO}$-supported platinum catalysts to evaluate the catalytic performance on the SRE reaction.

\section{EXPERIMENTAL}

\section{A. Preparation of support and catalyst}

Three kinds of prepared and commercial $\mathrm{ZnO}$ were used to prepare the $\mathrm{Pt} / \mathrm{ZnO}$ catalysts. $\mathrm{ZnO}-\mathrm{R}$ was prepared under reflux conditions, in which the equal molar ratio of $\mathrm{Zn}\left(\mathrm{NO}_{3}\right)_{2} \cdot 6 \mathrm{H}_{2} \mathrm{O}$ (Stream, 90\%) and urea (Stream, $90 \%)$ of 0.1 mole were stirred with DI water/ethanol $(80 / 20 \mathrm{~mL})$ at room temperature for $5 \mathrm{~min}$, then refluxed at $95^{\circ} \mathrm{C}$ for $12 \mathrm{~h}$. $\mathrm{ZnO}-\mathrm{A}$ and $\mathrm{ZnO}-\mathrm{N}$ were obtained through the thermal decomposition of $\mathrm{Zn}(\mathrm{OH})_{2} \cdot 2 \mathrm{ZnCO}_{3}$. $x \mathrm{H}_{2} \mathrm{O}$ (Stream, 99\%) in air and $\mathrm{N}_{2}$, respectively, at $300^{\circ} \mathrm{C}$ for $30 \mathrm{~min}$. The commercial $\mathrm{ZnO}$ (Sigma-Aldrich, 99\%) was denoted as $\mathrm{ZnO}-\mathrm{C}$.

The $\mathrm{Pt} / \mathrm{ZnO}$ catalysts were prepared by the incipient wetness impregnation method using $\mathrm{PtCl}_{4}$ (Stream, $\mathrm{Pt}=$ 99.9\%) as the precursor (3 wt\%), and denoted as Pt-R, Pt-N, Pt-A and Pt-C, respectively. The resulting solids were then dried at $110^{\circ} \mathrm{C}$ overnight and calcined in air at $300^{\circ} \mathrm{C}$ for $2 \mathrm{~h}$.

\section{B. Characterization of support and catalyst}

The reduction behavior of the $\mathrm{ZnO}$ supports and $\mathrm{Pt} / \mathrm{ZnO}$ catalysts was studied by temperatureprogrammed reduction (TPR). The sample was heated in $10 \% \mathrm{H}_{2} / \mathrm{N}_{2}$ (flow rate of $10 \mathrm{ml} \cdot \mathrm{min}$ ) with a heating rate of $7^{\circ} \mathrm{C} \cdot \mathrm{min}$ from ambient to $800^{\circ} \mathrm{C}$. The surface area $\left(\mathrm{S}_{\mathrm{BET}}, \mathrm{m}^{2} \cdot \mathrm{g}^{-1}\right)$ of the zinc oxide was determined with nitrogen adsorption isotherms measured at $-196^{\circ} \mathrm{C}$. $\mathrm{X}$-ray diffraction (XRD) measurements were performed using a MAC Science MXP18 diffractometer with $\mathrm{CuK} \alpha$ radiation $(\lambda=1.5405 \AA)$ at $40 \mathrm{kV}$ and $30 \mathrm{~mA}$. The crystallite sizes of the zinc oxide were estimated using the Scherrer equation. Transmission electron micrographs (TEM) were taken on a PHILIPS (CM-200) microscope at an accelerated voltage of $200 \mathrm{kV}$. Thermal gravimetric (TG) analysis was carried out using a Seiko SSC5000 TG system. The rate of heating was maintained at $10^{\circ} \mathrm{C} \cdot \mathrm{min}^{-1}$. The measurement was carried from RT to $600^{\circ} \mathrm{C}$ under an air-flow rate of $100 \mathrm{~mL} \cdot \mathrm{min}^{-1}$.

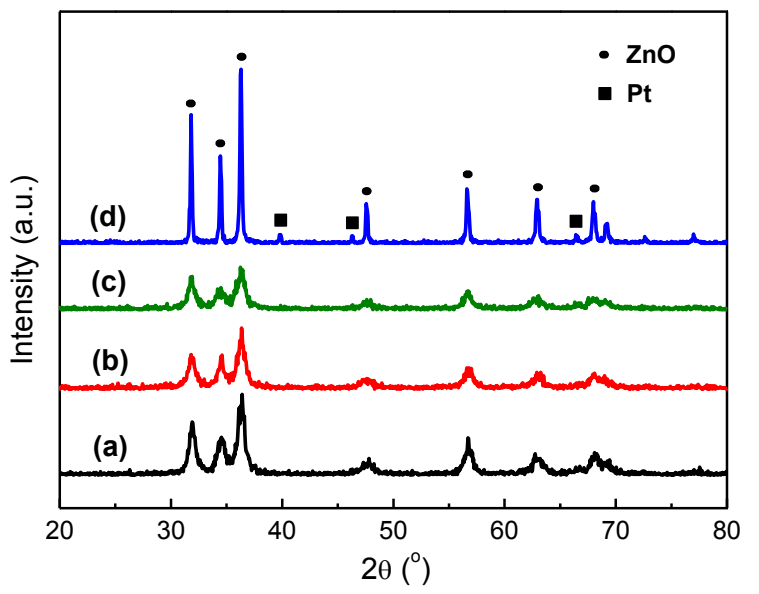

FIG. 2: XRD patterns of Pt/ZnO catalysts: (a) Pt-C (b) Pt-A (c) Pt-N (d) Pt-R.

\section{Evaluation of catalytic activity}

The catalytic activity of the $\mathrm{Pt} / \mathrm{ZnO}$ catalysts towards the SRE reaction was performed in a fixed-bed quartz reactor at atmospheric pressure. The gas hourly space velocity (GHSV) was maintained at $22,000 \mathrm{~h}^{-1}$ and the $\mathrm{H}_{2} \mathrm{O} / \mathrm{EtOH}$ molar ratio was $13\left(\mathrm{H}_{2} \mathrm{O}: \mathrm{EtOH}=80: 20\right.$ by volume). About $100 \mathrm{mg}$ of the catalysts with a $60-80$ mesh grain size were loaded into the reactor. Before the SRE reaction, the catalyst was activated by reduction with hydrogen at $200^{\circ} \mathrm{C}$ for $4 \mathrm{~h}$. The analysis of the reactants and products was carried out online by gas chromatography with columns of Porapak Q and Molecular Sieve 5 A for separation purposes. The evaluation of the SRE activity of the samples depended on the conversion of ethanol $\left(\mathrm{X}_{\mathrm{EtOH}}\right)$ and the distribution of products $(\mathrm{mol} \%)$.

$$
\begin{aligned}
\mathrm{X}_{\mathrm{EtOH}} & =n_{\mathrm{EtOH}, \text { reacted }} / n_{\mathrm{EtOH}, \text { fed }} \times 100[\%] \\
\mathrm{Y}_{\mathrm{H}_{2}} & =n_{\mathrm{H}_{2}-\text { out }} / n_{\mathrm{EtOH}, \text { reacted }} \\
\mathrm{S}_{i} & =n_{1} / \sum n_{i} \times 100[\%]
\end{aligned}
$$

where $\sum n_{i}$ included the $\mathrm{H}_{2}$.

\section{RESULTS AND DISCUSSIONS}

\section{A. Characterization of supports and catalysts}

The crystalline phase and structure of the $\mathrm{ZnO}$ supports were determined by XRD and showed in Fig. 1. The average particle size of the zinc oxide crystallite $(d \mathrm{ZnO})$ was calculated using the Scherrer's equation of the corresponding peaks and collected in Table I. The diffraction signals from XRD patterns showed the hexagonal phase of $\mathrm{ZnO}$ (JSPDS 89-1397) that were observed on all the $\mathrm{ZnO}$ supports. The intensity of the diffraction patterns of $\mathrm{ZnO}-\mathrm{R}$ support showed the better crystalline structure than the others, where the $\mathrm{ZnO}-\mathrm{R}$ had the largest particle size of $13 \mathrm{~nm}$ and smallest surface area of $1.3 \mathrm{~m}^{2} \cdot \mathrm{g}^{-1}$. Otherwise, the $\mathrm{ZnO}-\mathrm{A}$ had the smallest particle size of 4.9 $\mathrm{nm}$ and largest surface area of $89 \mathrm{~m}^{2} \cdot \mathrm{g}^{-1}$. The $\mathrm{ZnO}-\mathrm{N}$, 
TABLE I: Physical properties of $\mathrm{ZnO}$ supports and $\mathrm{Pt} / \mathrm{ZnO}$ catalysts.

\begin{tabular}{|c|c|c|c|c|c|c|}
\hline \multirow[t]{2}{*}{ Preparation method } & \multirow[t]{2}{*}{ Supports } & \multirow{2}{*}{$\begin{array}{c}\mathrm{S}_{\mathrm{BET}} \\
\left(\mathrm{m}^{2} / \mathrm{g}\right)\end{array}$} & \multirow[t]{2}{*}{ Catalysts } & \multicolumn{2}{|c|}{ Particle size (nm) } & \multirow{2}{*}{$\begin{array}{c}\text { Metal } \\
\text { loading }^{b}\end{array}$} \\
\hline & & & & $\mathrm{ZnO}^{a}$ & $\mathrm{Pt}^{a}$ & \\
\hline Commercial & $\mathrm{ZnO}-\mathrm{C}$ & 56 & $\mathrm{Pt}-\mathrm{C}$ & 5.4 & 7.5 & 2.3 \\
\hline Thermal decomposition-Air & $\mathrm{ZnO}-\mathrm{A}$ & 89 & Pt-A & 4.9 & 6.8 & 2.4 \\
\hline Thermal-decomposition- $\mathrm{N}_{2}$ & $\mathrm{ZnO}-\mathrm{N}$ & 55 & Pt-N & 5.7 & 6.3 & 2.4 \\
\hline Reflux & $\mathrm{ZnO}-\mathrm{R}$ & 1.3 & Pt-R & 13 & 16 & 2.4 \\
\hline
\end{tabular}

${ }^{a}$ Calculated from XRD with Scherrer's equation; ${ }^{b}$ Analysis from ICP-AES.

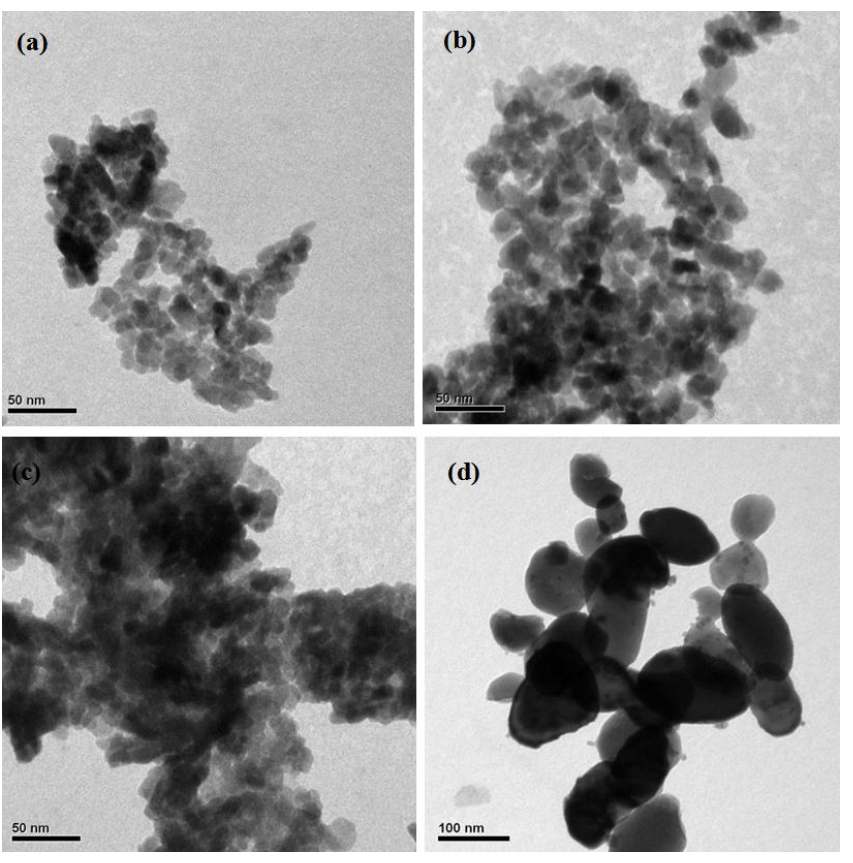

FIG. 3: TEM micrographs of Pt/ZnO catalysts: (a) Pt-C (b) Pt-A (c) Pt-N (d) Pt-R.

the similar preparation procedure with $\mathrm{ZnO}-\mathrm{A}$ but under $\mathrm{N}_{2}$ atmosphere as carrier gas, showed the larger particle size of $5.7 \mathrm{~nm}$ and smaller surface area of $55 \mathrm{~m}^{2} \cdot \mathrm{g}^{-1}$, where the similar data was found on commercial $\mathrm{ZnO}-\mathrm{C}$.

XRD patterns of the $\mathrm{Pt} / \mathrm{ZnO}$ catalysts were quite similar to that of the zinc oxide supports (shown in Fig. 2). Only Pt-R catalyst showed the additional diffraction peaks assigning to $\mathrm{Pt}$ (JSPDS 4-802). According to the literatures $[5,10]$ reported, the $\mathrm{ZnO}$ can promote the dispersion of metal and avoid the sintering of metal. Apparently, the surface area of $\mathrm{ZnO}$ can affect the dispersion of $\mathrm{Pt}$ on the $\mathrm{Pt} / \mathrm{ZnO}$ catalysts. Further, the particle size of $\mathrm{Pt} / \mathrm{ZnO}$ catalysts might influence the catalytic performance. Observed XRD data attributed that the Pt had poor dispersion (or aggregation) on the surface of $\mathrm{ZnO}-\mathrm{R}$. Moreover, the well dispersion and smaller particle size of $\mathrm{Pt}$ were found on Pt-C, Pt-N and Pt-A catalysts. From the TEM images (Fig. 3), the Pt-R catalyst presented a much larger crystalline size of $\mathrm{ZnO}$ than the others. The crystalline property and particle size of $\mathrm{ZnO}$ support from TEM were also convinced with the XRD analysis.

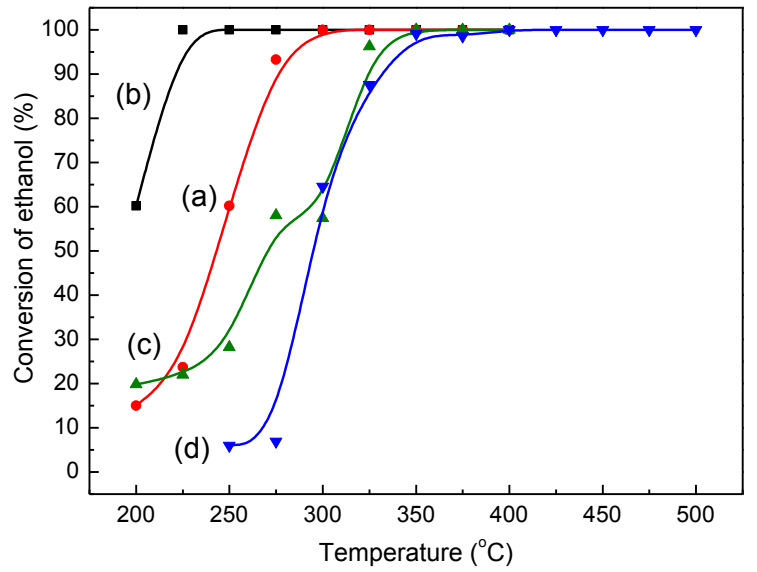

FIG. 4: Ethanol conversion over Pt/ZnO catalysts: (a) Pt-C (b) Pt-A (c) Pt-N (d) Pt-R.

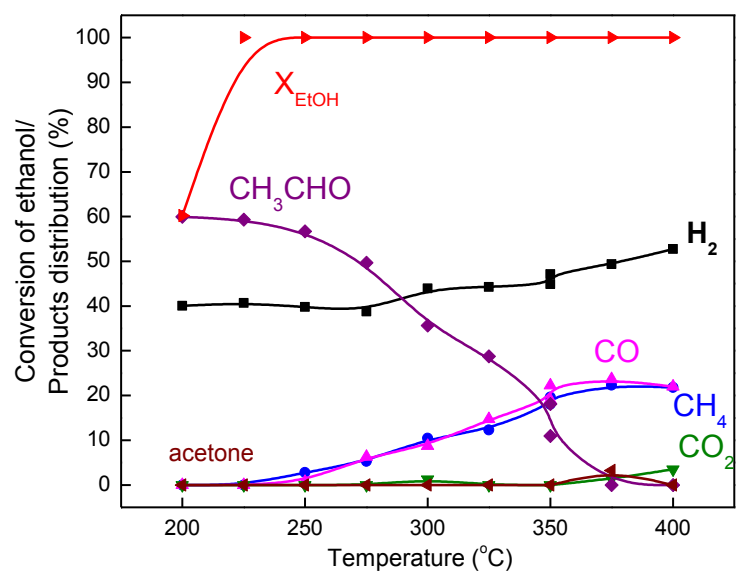

FIG. 5: Catalytic performance in the SRE reaction over Pt-A catalyst.

\section{B. Catalytic performance on the SRE reaction}

Figure 4 showed the ethanol conversion $\left(\mathrm{X}_{\mathrm{EtOH}}\right)$ over the $\mathrm{Pt} / \mathrm{ZnO}$ catalysts, where the temperature of $\mathrm{X}_{\mathrm{EtOH}}$ arrived complete was increased in the order: $\mathrm{Pt}-\mathrm{A}\left(225^{\circ} \mathrm{C}\right)$ $>\mathrm{Pt}-\mathrm{C}\left(300^{\circ} \mathrm{C}\right)>\mathrm{Pt}-\mathrm{N}\left(350^{\circ} \mathrm{C}\right)>\mathrm{Pt}-\mathrm{R}\left(400^{\circ} \mathrm{C}\right)$. The catalytic performance results were summarized in Table II. The ethanol conversion and products distribution of the Pt-R and Pt-A catalysts in the SRE reaction at different reaction temperatures $\left(T_{\mathrm{R}}\right)$ were shown in Figs. 5 and 6 , respectively. 
TABLE II: Products distribution of $\mathrm{Pt} / \mathrm{ZnO}$ catalysts.

\begin{tabular}{|c|c|c|c|c|c|c|c|c|}
\hline \multirow[t]{2}{*}{ Catalyst } & \multirow[t]{2}{*}{$\mathrm{TR}\left({ }^{\circ} \mathrm{C}\right)$} & \multirow[t]{2}{*}{$\mathrm{X}_{\mathrm{EtOH}}(\%)$} & \multicolumn{6}{|c|}{ Products distribution $(\%)^{a}$} \\
\hline & & & $\mathrm{H}_{2}$ & $\mathrm{CH}_{4}$ & $\mathrm{CO}$ & $\mathrm{CO}_{2}$ & $\mathrm{C}_{2} \mathrm{H}_{4} \mathrm{O}$ & $\mathrm{C}_{3} \mathrm{H}_{6} \mathrm{O}$ \\
\hline \multirow{5}{*}{ Pt-C } & 200 & 13.7 & 49.0 & - & - & - & 51.0 & - \\
\hline & 250 & 60.2 & 49.8 & 2.19 & 0.59 & - & 47.4 & - \\
\hline & 300 & 100 & 51.9 & 9.50 & 9.70 & 1.06 & 27.9 & - \\
\hline & 350 & 100 & 58.5 & 12.6 & 12.0 & 1.66 & 15.4 & - \\
\hline & 400 & 100 & 68.4 & 14.0 & 5.00 & 12.6 & - & - \\
\hline \multirow{5}{*}{ Pt-A } & 200 & 60.2 & 40.0 & - & - & - & 60.0 & - \\
\hline & 250 & 100 & 39.8 & 2.79 & 0.70 & - & 56.7 & - \\
\hline & 300 & 100 & 43.9 & 10.4 & 8.72 & 1.27 & 35.7 & - \\
\hline & 350 & 100 & 44.9 & 18.0 & 19.0 & - & 18.1 & - \\
\hline & 400 & 100 & 49.4 & 22.3 & 23.7 & 1.40 & - & 3.25 \\
\hline \multirow{5}{*}{ Pt-N } & 200 & 19.8 & 58.3 & - & - & - & 41.8 & - \\
\hline & 250 & 28.2 & 61.6 & - & - & - & 38.4 & - \\
\hline & 300 & 57.4 & 60.4 & 2.41 & 5.02 & - & 32.2 & - \\
\hline & 350 & 100 & 57.1 & 15.6 & 17.0 & 1.36 & 9.00 & - \\
\hline & 400 & 100 & 62.1 & 21.0 & 13.5 & 3.36 & - & - \\
\hline \multirow{5}{*}{ Pt-R } & 300 & 64.5 & 51.9 & - & - & - & 48.1 & - \\
\hline & 350 & 99.1 & 59.0 & - & - & - & 41.0 & - \\
\hline & 400 & 100 & 56.3 & 11.3 & 3.00 & 10.0 & 18.1 & 1.27 \\
\hline & 450 & 100 & 64.2 & 18.3 & - & 14.4 & - & 3.16 \\
\hline & 500 & 100 & 69.8 & 13.8 & - & 13.7 & - & 2.66 \\
\hline
\end{tabular}

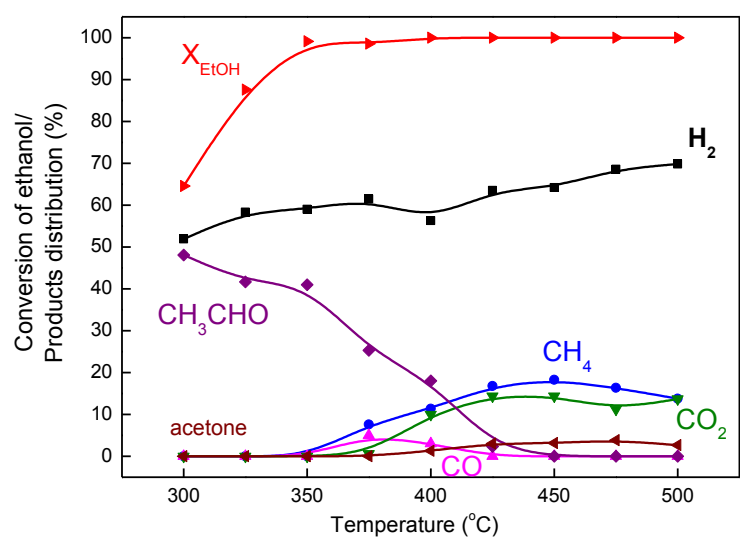

FIG. 6: Catalytic performance in the SRE reaction over Pt-R catalyst.

The major product of acetaldehyde at low temperature demonstrated that the preferentially erased hydrogen from ethanol by the prepared $\mathrm{Pt} / \mathrm{ZnO}$ catalysts [Eq. (4)]:

$$
\mathrm{CH}_{3} \mathrm{CH}_{2} \mathrm{OH} \rightarrow \mathrm{CH}_{3} \mathrm{CHO}+\mathrm{H}_{2} \text {. }
$$

The ability to erase hydrogen was enhanced with the increased surface area of the zinc oxide support, while the breakage of the $\mathrm{C}-\mathrm{C}$ bond for the $\mathrm{Pt} / \mathrm{ZnO}$ catalysts was worse at temperatures below $300^{\circ} \mathrm{C}$. Also, we found that only minor $\left(\mathrm{CH}_{3}\right)_{2} \mathrm{CO}$ formed at temperatures exceeding $350^{\circ} \mathrm{C}$ via the aldol condensation of ethanol, as shown in Eq. (5). Similar observations and explanations have also been suggested by other researchers [27]:

$$
2 \mathrm{C}_{2} \mathrm{H}_{5} \mathrm{OH} \rightarrow \mathrm{CH}_{3} \mathrm{COCH}_{3}+\mathrm{CO}+\mathrm{H}_{2} \text {. }
$$

Comparison the hydrogen distribution over Pt-R and Pt-A catalysts, Pt-R catalyst was higher than Pt-A catalyst with $T_{\mathrm{R}}$ increasing. At temperatures as high as $350^{\circ} \mathrm{C}$, both catalysts appeared actively to break the $\mathrm{C}-$ $\mathrm{C}$ bond and promoted $\mathrm{H}_{2}$ production which came from the decomposition of acetaldehyde to $\mathrm{CH}_{4}$ and $\mathrm{CO}$ or reformed to $\mathrm{H}_{2}$ and $\mathrm{CO}_{2}$. Since the $\mathrm{CH}_{4}$ formation occurred through the possible reforming reactions [27], two competitive paths of acetaldehyde have been proposed. The decomposition of acetaldehyde [Eq. (6)] was preferred for the small particle size catalyst of $\mathrm{Pt}-\mathrm{A}$ to form $\mathrm{CH}_{4}$ and $\mathrm{CO}$ since the ratio of $\mathrm{CH}_{4} / \mathrm{CO}$ approached one; while the steam reforming of acetaldehyde [Eq. (7)] was preferred for the large particle size catalyst of $\mathrm{Pt}-\mathrm{R}$ to form $\mathrm{CH}_{4}$ and $\mathrm{CO}_{2}$. This tendency indicated that the steam reforming of acetaldehyde was thermodynamically feasible at high temperature.

$$
\begin{aligned}
\mathrm{C}_{2} \mathrm{H}_{4} \mathrm{O} & \rightarrow \mathrm{CH}_{4}+\mathrm{CO} \\
\mathrm{C}_{2} \mathrm{H}_{4} \mathrm{O}+\mathrm{H}_{2} \mathrm{O} & \rightarrow \mathrm{CH}_{4}+\mathrm{CO}_{2}+\mathrm{H}_{2} .
\end{aligned}
$$

A comparison of the characterizations of the catalysts indicated that the steam reforming of acetaldehyde was favorable for the catalyst with a large crystal size of zinc oxide $[5,6]$. The worse dispersion of platinum on the large crystal size of $\mathrm{ZnO}-\mathrm{R}$ impelled the aggregation of platinum on the surface and depressed the rate of decomposition of acetaldehyde. Contrarily, the large crystal size of the zinc oxide-supported catalyst provided an adsorption site for water [28] to promote the steam reforming of acetaldehyde. As the particle size of the platinum catalyst decreased, the activity on the decomposition of acetaldehyde would be increased and shifted to a lower temperature.

According to the evaluation of catalytic activity on the SRE reaction, we suggested that the surface area of the zinc oxide influenced the activity and selectivity of products on the $\mathrm{Pt} / \mathrm{ZnO}$ catalysts. A high surface area of the zinc oxide-supported catalyst tended to push the catalyst executing the decomposition of acetaldehyde, such 


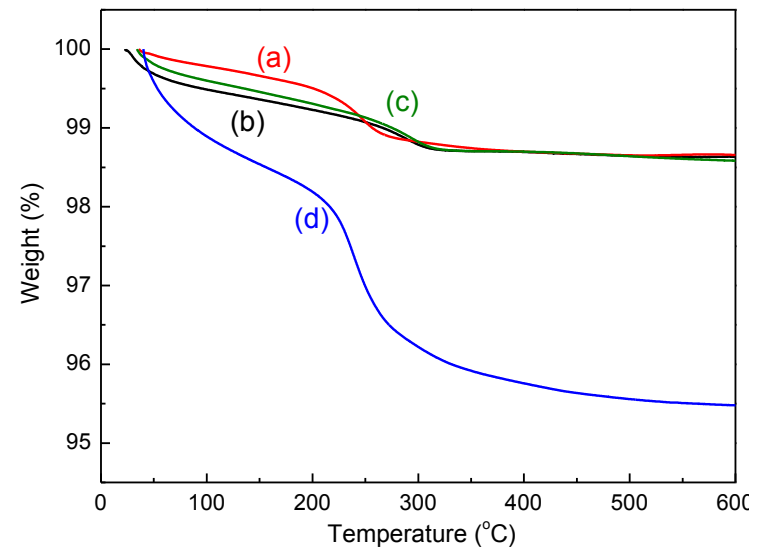

FIG. 7: TG profiles of spent catalysts: (a) Pt-C (b) Pt-A (c) Pt-N (d) Pt-R.

as Pt-A, Pt-N and Pt-C catalysts. The distribution of both $\mathrm{CH}_{4}$ and $\mathrm{CO}$ can not deplete with the $T_{\mathrm{R}}$ to depress the production of hydrogen, which indicated that a water gas shift (WGS) reaction was difficult occurred on the Pt$\mathrm{A}, \mathrm{Pt}-\mathrm{N}$ and $\mathrm{Pt}-\mathrm{C}$ catalysts. The minor $\mathrm{CO}$ distribution over Pt-R catalyst indicated that the low surface area of the $\mathrm{ZnO}$-supported catalyst tended to execute the steam reforming of the acetaldehyde.

Based on the evaluation of catalytic performance over $\mathrm{Pt} / \mathrm{ZnO}$ catalysts, the surface area of supported-platinum catalysts was decreased in the order: $\mathrm{Pt}-\mathrm{A}>\mathrm{Pt}-\mathrm{C} \approx \mathrm{Pt}-$ $\mathrm{N}>\mathrm{Pt}-\mathrm{R}$, which was confirmed with the order of $\mathrm{X}_{\mathrm{EtOH}}$. Moreover, the support with large surface area possessed the small particle size not only of support but also of active metal (see Table I). Apparently, the surface area and particle size of the support and catalyst can influence the catalytic activity.

\section{Characterization of used catalysts}

The stability of the active component, sintering of active species and the deposition of coke were the key rea- sons for the catalyst deactivation in the SRE reaction. In order to obtain more information about the stability of $\mathrm{Pt} / \mathrm{ZnO}$ catalysts, characterization of TG analysis was pursued for samples after the SRE catalytic tests. The TG curves for the spent catalysts showed in Fig. 7. The weight loss at the temperature range of $200-285^{\circ} \mathrm{C}$ was assigned for the combustion of adsorbed $\mathrm{C}_{1}$ species (i.e. $\mathrm{CH}_{x}$ and $\mathrm{CO}_{x}$ ) on the surface of catalyst. According to the competitive paths of acetaldehyde intermediate, the $\mathrm{C}_{1}$ species could be deposited on the catalyst's surface. Furthermore, the combustion of coke approached $450-550^{\circ} \mathrm{C}$, as reported in the literature; the deposition of coke was unnoticeable over the four $\mathrm{ZnO}$-supported catalysts.

\section{CONCLUSIONS}

The zinc oxide-supported platinum catalysts were evaluated, where the surface area of the $\mathrm{ZnO}$ support played an important role not only in the activity for the steam reforming of the ethanol, but also in the selectivity for the products. The Pt-A catalyst had a complete conversion of ethanol and over $40 \% \mathrm{H}_{2}$ selectivity could be obtained at a low temperature of $225^{\circ} \mathrm{C}$. On the other hand, the Pt-R catalyst had a higher hydrogen distribution accompanied with a high reaction temperature. For the platinum-based catalysts, the high surface area of the zinc oxide-supported catalyst tended to execute the decomposition of acetaldehyde; otherwise, a low surface area of zinc oxide-supported catalyst promoted the steam reforming of acetaldehyde.

\section{Acknowledgments}

We are pleased to acknowledge the financial support for this study by the National Science Council of the Republic of China under contract numbers of NSC 99-2113-M-606001-MY3 and 98-2627-M-606-001.
[1] M. A. Peña, J. P. Gómez, and J. L. G. Fierro, Appl. Catal. A 144, 7 (1996).

[2] J. N. Armor, Appl. Catal. A 176, 159 (1999).

[3] F. Joensen and J. R. Rostrup-Nielsen, J. Power Sources 105, 195 (2002)

[4] J. Llorca, P. R. de la Piscina, J. Sales, and N. Homs, Chem. Commun. 641 (2001).

[5] J. Llorca, N. Homs, J. Sales, and P. R. de la Piscina, J. Catal. 209, 306 (2002).

[6] J. Llorca, J. A. Dalmon, P. R. de la Piscina, and N. Homs, Appl. Catal. A 243, 261 (2003).

[7] Y. Yang, J. X. Ma, and F. Wu, Int. J. Hydrogen Energy 31, 877 (2006).

[8] E. Seker, Int. J. Hydrogen Energy 33, 2044 (2008).

[9] X. Deng, J. Sun, S. Yu, J. Xi, W. Zhu, and X. Qiu, Int. J. Hydrogen Energy 33, 1008 (2008).

[10] J. Llorca, P. R. de la Piscina, J. A. Dalmon, J. Sales, and N. Homs, Appl. Catal. B 43, 355 (2003).
[11] J. M. Guil, N. Homs, J. Llorca, and P. R. de la Piscina, J. Phys. Chem. B 109, 10813 (2005).

[12] Y. Yang, J. Ma, and F. Wu, Int. J. Hydrogen Energy 31, 877 (2006).

[13] N. Homs, J. Llorca, and P. R. de la Piscine, Catal. Today 116, 361 (2006).

[14] J. F. da Costa-Serra, R. Guil-López, and A. Chica, Int. J. Hydrogen Energy 35, 6709 (2010).

[15] K. S. Kim and Y. K. Lee, Int. J. Hydrogen Energy 35, 5378 (2010).

[16] A. Casanovas, M. Roig, C. de Leitenburg, A. Trovarelli, and J. Llorca, Int. J. Hydrogen Energy 35, 7690 (2010).

[17] Y. K. Lee, K. S. Kim, J. G. Ahn, I. H. Son, and W. C. Shin, Int. J. Hydrogen Energy 35, 1147 (2010).

[18] S. M. de Lima, A. M. da Silva, G. Jacobs, B. H. Davis, L. V. Mattos, and F. B. Noronha, Appl. Catal. B 96, 387 (2010).

[19] L. V. Mattos and F. B. Noronha, J. Power Sources 145, 
$10(2005)$.

[20] L. V. Mattos and F. B. Noronha, J. Catal. 233, 453 (2005).

[21] G. Jacobs, R. A. Keogh, and B. H. Davis, J. Catal. 245, 326 (2007).

[22] S. M. de Lima, I. O. da Cruz, G. Jacobs, B. H. Davis, L. V. Mattos, and F. B. Noronha, J. Catal. 257, 356 (2008).

[23] M. C. Sanchez-Sanchez, R. M. N. Yerga, D. I. Kondarides, X. E. Verykios, and J. L. G. Fierro. J. Phys. Chem. A 114, 3873 (2010).
[24] J. L. Bi, Y. Y. Hong, C. C. Lee, C. T. Yeh, and C. B. Wang, Catal. Today 129, 322 (2007).

[25] J. L. Bi, S. N. Hsu, C. T. Yeh, and C. B. Wang, Catal. Today 129, 330 (2007).

[26] S. N. Hsu, J. L. Bi, W. F. Wang, C. T. Yeh, and C. B. Wang, Int. J. Hydrogen Energy 33, 693 (2008).

[27] A. Kiennemann, H. Idriss, R. Kieffer, P. Chaumette, and D. Durand, Ind. Eng. Chem. Res. 30, 1130 (1991).

[28] D. Chadwick and K. Zheng, Catal. Lett. 20, 231 (1993). 